\title{
Different Manner of DNA Synthesis in Polyploidizations of Meth-A and B16F10 Cell Lines
}

\author{
Kohzaburo Fujikawa-Yamamoto ${ }^{1, *}$, Zhi-ping Zong ${ }^{1}$, Manabu Murakami ${ }^{1}$, and Shizuo Odashima ${ }^{2}$ \\ ${ }^{1}$ Division of Basic Science, Research Institute of Medical Science and ${ }^{2}$ Department of Pathology, Kanazawa \\ Medical University, Uchinada, Ishikawa 920-02, Japan
}

Key words: DNA synthesis/polyploidization/Meth-A cells/B16F10 cells

\begin{abstract}
Polyploidization of Meth-A and B16-F10 cells by demecolcine was examined using flow cytometry (FCM). In the presence of demecolcine, both cell lines were polyploidized to more than 16c DNA content. A marked difference was observed in the durations of $S$ phase of polyploidy. The S-phase duration of Meth-A cells was doubly increased with ploidy, but that of B16F10 cells remained constant. When the rate of DNA synthesis in the polyploidizing cells was examined through the BrdU-uptake experiments, it was confirmed that the level of DNA-synthesis rate was constant in Meth-A cells but increased in B16F10 cells. The cellular content of c-Myc protein in polyploidized cells was also examined using anti-c-Myc monoclonal antibody. The c-Myc level of Meth-A cells was constant regardless of the ploidy but that of B16F10 cells increased with ploidy. Thus, the cMyc content seems to be related to the duration of $S$ phase in polyploidy.
\end{abstract}

A relationship between DNA synthesis rate and DNA content has been reported for Chinese hamster cells by Graves and McMillan (6). They concluded that the duration of $\mathrm{S}$ phase in mammalian cells is almost constant regardless of the DNA content. This was supported by the finding of the increasing BrdU uptake in polyploid CHO cells (13).

Constant rate of cell-cycle progression in polyploidizing cells has been demonstrated in human lymphocytic leukemic MOLT-4 cells by Gong et al. (5) and in V79 cells by us (3), suggesting that intracellular contents of enzymes and precursors relating to DNA synthesis increased with the ploidy increase. However, the duration of each phase of polyploidized cells has not been examined. If the duration of S phase is almost constant, how does the durations of $\mathrm{G}_{1}$ and $\mathrm{G}_{2}$ phase increase in polyploidy?

To confirm whether or not the durations of $\mathrm{G}_{1}$ and $\mathrm{G}_{2}$ phases elongate with the ploidy increase, we examined cell cycle parameters of polyploidizing Meth-A and B16F10 cells. Methylcholanthrene-derived murine abdominal dropsy tumor cells (Meth-A cells) in culture always contain large cells which are self-induced polyploid Meth-A cells. Meth-A cells were polyploidized by demecolcine, K-252a and staurosporine (4). B16F10 cells, selected as a control, were polyploidized by demecolcine and K-252a but not by staurosporine (4). Here,

\footnotetext{
* To whom correspondence and reprint requests should be addressed.

Tel: +81-762-86-2211 ext. 3960, Fax: $+81-762-86-3652$
}

we demonstrated an exception that the rate of DNA synthesis is constant in Meth-A cells, independent of the ploidy.

\section{MATERIALS AND METHODS}

Cells. Murine abdominal dropsy tumor cells (Meth-A cells) were maintained in a humidified atmosphere of $5 \% \mathrm{CO}_{2}$ at $37^{\circ} \mathrm{C}$ as suspension culture in a Leibovitz's L15:Ham's F10 mixture (7:3) supplemented with $10 \%$ fetal bovine serum, streptomycin $(100 \mathrm{mg} / \mathrm{ml})$ and penicillin $(50$ units $/ \mathrm{ml})$. B16F10 cells, a highly metastatic subline of mouse B16 melanoma cells, were maintained under the same conditions as above except that they were cultured in monolayers. Both cell lines were cultured at low density.

Synchronization of cell lines. Exponentially growing Meth-A and B16F10 cells were plated in Petri dishes $(100 \mathrm{~mm}$ diameter, NUNC) at a density of about $2 \times 10^{5}$ and $1 \times 10^{5}$ cells/dish, respectively, with the medium being changed $24 \mathrm{~h}$ after seeding. Twelve hours thereafter, the cells were exposed to hydroxyurea $(\mathrm{HU})$ at a final concentration of $0.6 \mathrm{mM}$. Five hours thereafter, the Meth-A cells were washed twice by centrifugation and the B16F10 cells were rinsed twice with medium. Two hours after HU release, the cells were exposed to demecolcine as follows.

Polyploidization of synchronized cell lines. The synchronized cells were exposed to demecolcine at a final concentration of $0.1 \mu \mathrm{g} / \mathrm{ml}$. At various times, as shown in Fig. 2, Meth$\mathrm{A}$ and B16F10 cells were fixed with $20 \%$ ethanol/PBS ${ }^{(-)}$(divalent cation-free phosphate buffered saline) and stored at $4^{\circ} \mathrm{C}$. B16F10 cells were trypsinized $(0.17 \%$ trypsin and $30 \mathrm{mM}$ 
EDTA) before the ethanol fixation.

The fixed cells were incubated with $0.25 \%$ RNase (Type IIA, Sigma Chemical Co.) for $3 \mathrm{~h}$ at $4{ }^{\circ} \mathrm{C}$. Immediately prior to measurements, the cells were stained with PI solution (propidium iodide, $7.5 \times 10^{-5} \mathrm{M}$ ) and examined for red fluorescence by flow cytometry (FCM). Under these staining conditions, the signal due to residual double-stranded RNA is negligible and the relative intensity of red fluorescence corresponds to the DNA content (8).

DNA synthesis in polyploid cells. Exponentially growing Meth-A and B16F10 cells were plated in Petri dishes $(60 \mathrm{~mm}$ diameter, NUNC) at a density of about $2 \times 10^{5}$ and $1 \times 10^{5}$ cells/dish, respectively, with the medium being changed $24 \mathrm{~h}$ after seeding. Twenty-four hours thereafter, the cells were exposed to demecolcine at a final concentration of $0.1 \mu \mathrm{g} / \mathrm{ml}$. At various times, the cells were exposed to 5-bromodeoxyuridine (BrdU, Wako Pure Chemical Industries, Ltd.) at a final concentration of $10 \mathrm{mM}$ for $30 \mathrm{~min}$. The cells were washed with $\mathrm{PBS}^{(-)}$, fixed with $20 \%$ ethanol and stored at $4{ }^{\circ} \mathrm{C}$.

The fixed cells were incubated with $0.25 \% \mathrm{RNase}$ for $3 \mathrm{~h}$ at $4^{\circ} \mathrm{C}$, after which they were treated with $2 \mathrm{~N} \mathrm{HCl}$ for $45 \mathrm{~min}$ at $25^{\circ} \mathrm{C}$, and then neutralized with $0.1 \mathrm{M} \mathrm{Na}_{2} \mathrm{~B}_{4} \mathrm{O}_{7}(\mathrm{pH} 8.5)$. A $1 \times 10^{6}$ cell suspension in $100 \mu \mathrm{PBS}^{-)}$containing $2 \%$ BSA (bovine serum albumin), $0.5 \%$ Tween 20 and $5 \mu \mathrm{g}$ anti-BrdU monoclonal antibody (Becton Dickinson) was then incubated for $12 \mathrm{~h}$ at $4^{\circ} \mathrm{C}$. After these cells had been washed 3 times with washing solution PBS $^{(-)}$containing $0.5 \%$ Tween 20 and $2 \%$ BSA), they were stained with FITC-conjugated rabbit antimouse IgG (E.Y. Labs. Inc.) to BrdU for $1 \mathrm{~h}$ at room temperature (RT). The cells were stained with PI solution and examined by FCM for green and red fluorescences, which correlated to BrdU and DNA content, respectively.

Measurements of $c-M y c$ protein in polyploid cells. Exponentially growing Meth-A and B16F10 cells were plated in Petri dishes ( $60 \mathrm{~mm}$ diameter, NUNC) at a density of about 2 $\times 10^{5}$ and $1 \times 10^{5}$ cells/dish, respectively, with the medium being changed $24 \mathrm{~h}$ after seeding. Twenty-four hours thereafter, the cells were exposed to demecolcine at a final concentration of $0.1 \mu \mathrm{g} / \mathrm{ml}$. At various times, the cells were harvested, fixed with $20 \%$ ethanol, then treated with RNase as described above.

A $1 \times 10^{6}$ cell suspension in $100 \mu \mathrm{PBS}^{(-)}$containing $0.5 \%$ Tween 20, 2\% BSA and $5 \mu \mathrm{l}$ of anti-c-Myc monoclonal antibody (Cambridge Res. Biochem. Ltd.) was incubated for 30 min at RT. The cells were washed 3 times with washing solution, and then stained with FITC-conjugated rabbit antimouse IgG (E.Y. Labs. Inc.) for $30 \mathrm{~min}$ at RT. The cells were stained with PI solution and examined by FCM for green and red fluorescences, which correlated to c-Myc protein and DNA content, respectively.

Flow Cytometry (FCM). Fluorescence from individual cells was measured with a Cytofluorograf system $50 \mathrm{H}$ (Ortho Instruments) and a Facsort (Becton Dickinson Immunocytometry Systems). The fluorescence of individual cells irradiated with a focused laser light at a wavelength of $488 \mathrm{~nm}$ was de- tected by photomultiplier tubes. Relative intensities of green and red fluorescence were measured, and DNA histograms were obtained. FCM measurements were performed as soon as possible after sample preparation.

\section{RESULTS}

To examine the cell cycle parameters of polyploidizing Meth-A and B16F10 cells, the cells were partially synchronized by $\mathrm{HU}$ to exclude $\mathrm{G}_{2} / \mathrm{M}$ phase cells and exposed to demecolcine. At various times, the DNA distribution of cell population was obtained by FCM. Figure 1 shows representative DNA fluorescence histogram of Meth-A and B16F10 cells after the addition of demecolcine. In Fig. 1, 16c and 32c DNA peaks appeared on the histograms at 96 (C in Fig. 1) and $112 \mathrm{~h}$ (F in Fig. 1) after the drug addition to B16F10 and Meth-A cells, respectively, suggesting that both cell lines were polyploidized by demecolcine.

In Fig. 1, histograms $\mathrm{C}$ and $\mathrm{F}$ contain more than three peaks, indicating that not all of the cells in the population were polyploidized. A large fraction of the shoulder population appeared in the histogram of the Meth-A cell population ( $F$ in Fig. 1). They belong to the cell debris of dead cells and due to the lack of medium change.

To quantify the cell-cycle response after drug exposure, the DNA contents of the main peaks (most frequent peaks) and the sub-peaks (those other than the main peaks) were plotted against time after demecolcine addition (Fig. 2). In Fig. 2, the solid lines were drawn by considering the peaks of the most progressive subpopulations that had the maximum DNA content at the time. In drawing the $\mathrm{S}$ phase, the shoulders in the histograms were taken into account. Panel B in Fig. 2 represents the results of two independent experiments. Figure 2 reveals that the DNA content of Meth-A and B16F10 cells increased step by step from $2 \mathrm{c}$ to above $16 \mathrm{c}$, implying progressive polyploidization.

The cell cycle parameters of the polyploidizing cells are listed in Table $\mathrm{I}$. The cell cycle time (defined as $\mathrm{G}_{2}$ $/ \mathrm{M}$ phase of lower ploidy plus $\mathrm{G}_{1} / \mathrm{S}$ phase of higher ploidy) gradually increased with a ratio of about 1.5 in both cell lines. In the Meth-A cell population, the length of the $\mathrm{S}$ phase increased at 4.2, 8.3, 14.2 and $29.6 \mathrm{~h}$ with the ploidy increase but was a constant $6 \mathrm{~h}$ in the B16F10 cells. These findings suggest that the Sphase duration is not always constant in polyploidization.

To examine the rate of DNA synthesis in the polyploidized Meth-A and B16F10 cells, BrdU uptake in these polyploidized cells was measured by FCM using anti-BrdU monoclonal antibody (Fig. 3). Figure 3 shows the BrdU/DNA cytograms and the DNA histograms (the insert figure) of polyploidizing Meth-A and 

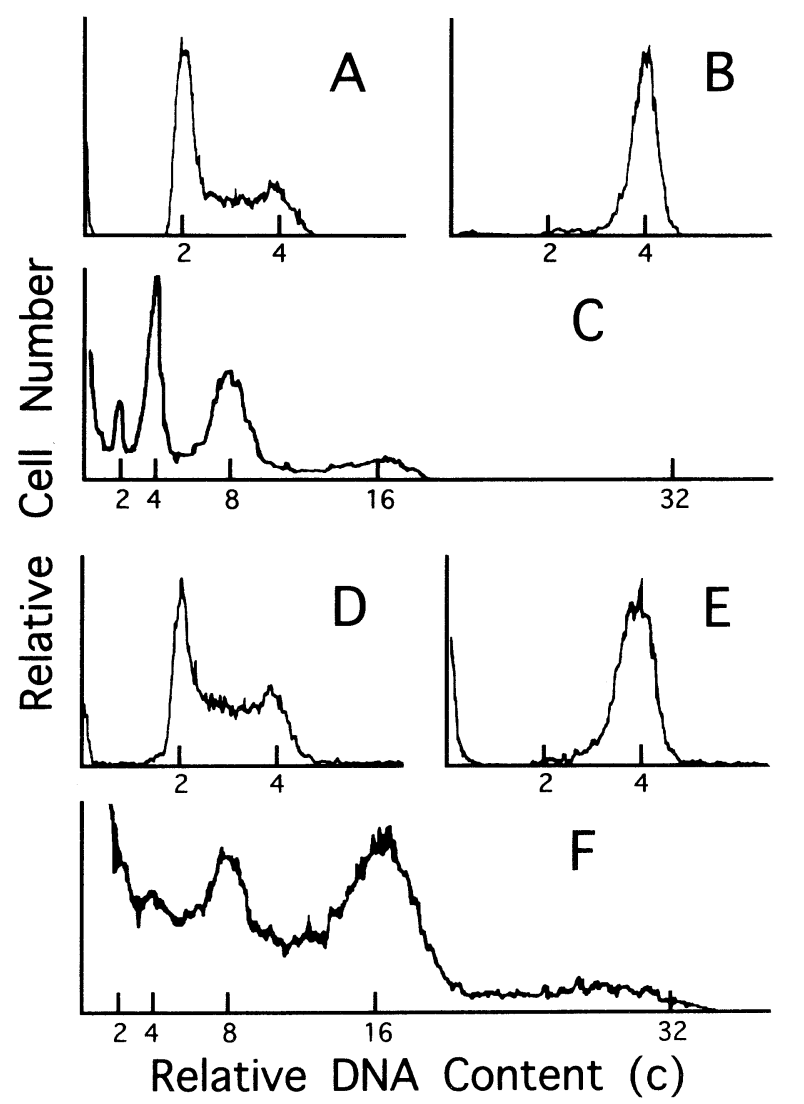

Fig. 1. Representative DNA histograms of B16F10 (A, B and C) and Meth-A (D, E and F) cells. Two hours after HU release, the cells were exposed to demecolcine of $0.1 \mu \mathrm{g} / \mathrm{ml}$. At various times, DNA histograms were obtained. The ordinate represents the relative cell number and the abscissa, the relative DNA content (c). Panels A and $\mathrm{D}$ are of the control, and panels $\mathrm{B}$ and $\mathrm{E}$, the histograms $12 \mathrm{~h}$ after demecolcine addition. Panels $\mathrm{C}$ and $\mathrm{F}$ represent the histograms 96 and $112 \mathrm{~h}$ after the drug addition, respectively.

B16F10 cells. The relative content of BrdU incorporated in cells was estimated in the mid $\mathrm{S}$ phases, and the results are listed in Table I. The BrdU uptake relating to DNA synthesis rate was increased with the ploidy increase in both cell lines, but the manner of increase was essentially different. The rate increased doubly as 1.0 , 4.0 and 8.4 in B16F10 cells but was almost constant as $1.0,1.2$ and 1.8 in Meth-A cells.

To explain the difference in the DNA synthesis rate between Meth-A and B16F10 cells, we measured the cellular content of c-Myc protein, which might be related to the DNA synthesis, using an anti-c-Myc monoclonal antibody (Fig. 4). Figure 4 shows the c-Myc/DNA cytograms of Meth-A and B16F10 cells. The relative content of c-Myc in cells was estimated in the mid S phases, and the findings are listed in Table I. The c-Myc content was increased with ploidy increase in both cell lines, but the manner of increase, as well as that of the BrdU uptake
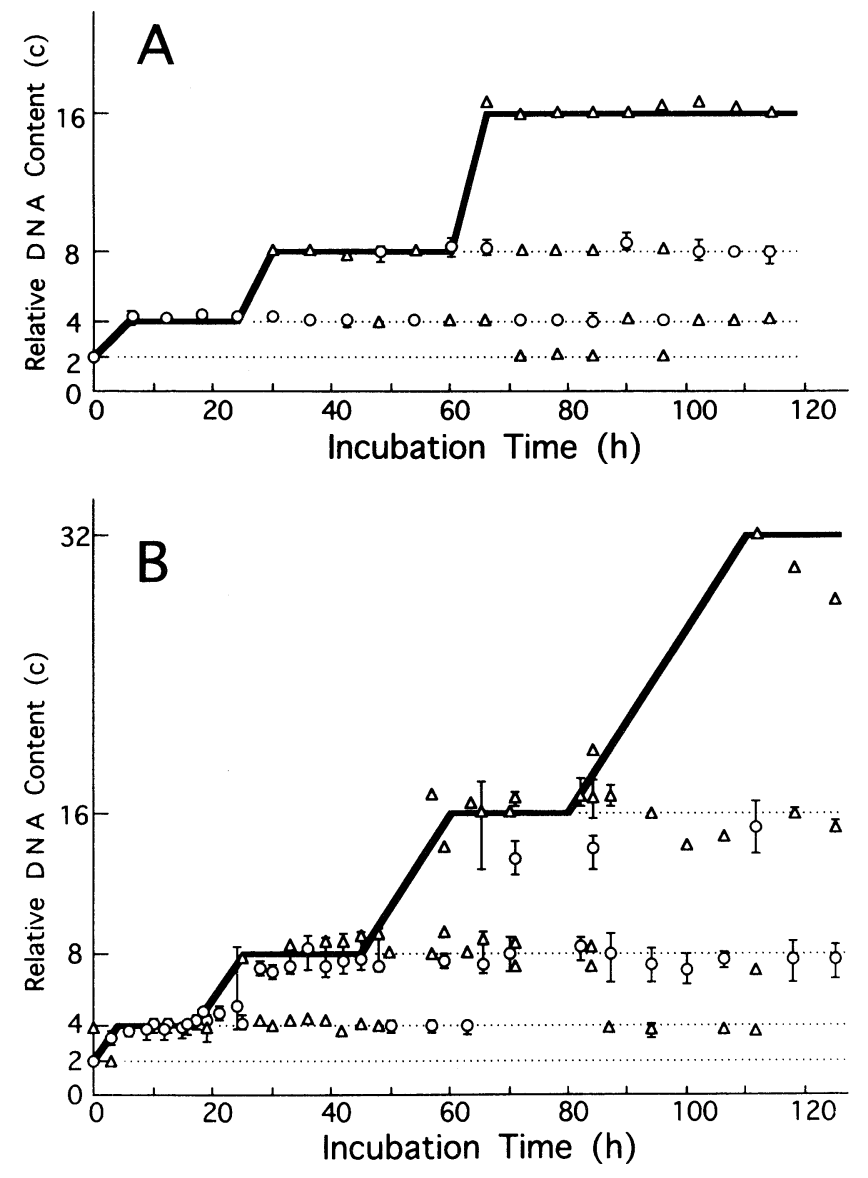

Fig. 2. Changes in DNA content of synchronized B16F10 (A) and Meth-A (B) cell populations. Two hours after HU release, the cells were exposed to demecolcine. At various times, DNA histograms were obtained, and the DNA content of the peaks in histograms was determined. The ordinate represents the relative DNA content and the abscissa, the time after demecolcine addition. Open circles represent DNA content at the main peaks (most populated peak), and triangles represent those of the sub-peaks. Longitudinal bars indicate the peak width at $70 \%$ of the height of the main peak. The solid lines were drawn to express the DNA content of subpopulations which contained the highest level of DNA at that time. Dotted lines were drawn for clarity.

was essentially different. The c-Myc content increased doubled as 1.0, 2.8 and 4.8 in B16F10 cells but was almost constant as 1.0, 1.2 and 1.4 in Meth-A cells. We concluded that the constant level in c-Myc content is responsible for the elongation of the S-phase duration and the constant rate of DNA synthesis in the polyploidizing process of Meth-A cells.

\section{DISCUSSION}

Polyploid cells are observed in various organs, particularly in the aged or partial hepatectomized liver, but the mechanism of polyploidization is unclear $(9,10$, 
Table I. The Cell Cycle parameters in polyploidizing B16F10 and Meth-A Cells.

\begin{tabular}{|c|c|c|c|c|c|c|c|c|}
\hline $\begin{array}{l}\text { Phase } \\
\text { DNA level }\end{array}$ & $\begin{array}{c}\mathrm{S} \\
(2 \mathrm{c}-4 \mathrm{c})\end{array}$ & $\mathrm{G}_{2}+\underset{4 \mathrm{c}}{\mathrm{M}}+\mathrm{G}_{1}$ & $\begin{array}{c}\mathrm{S} \\
(4 \mathrm{c}-8 \mathrm{c})\end{array}$ & $\underset{8 \mathrm{c}}{\mathrm{G}_{2}+\mathrm{G}_{1}}$ & $\begin{array}{c}S \\
(8 c-16 c)\end{array}$ & $\begin{array}{c}\mathrm{G}_{2}+\underset{16 \mathrm{c}}{\mathrm{M}}+\mathrm{G}_{1} \\
\end{array}$ & $\begin{array}{c}S \\
(16 c-32 c)\end{array}$ & $\begin{array}{c}\mathrm{G}_{2}+\underset{32 \mathrm{c}}{\mathrm{M}}+\mathrm{G}_{1} \\
\end{array}$ \\
\hline \multicolumn{9}{|l|}{$\langle\mathrm{B} 16 \mathrm{~F} 10$ cells $\rangle$} \\
\hline Phase Durations (h) & 6.0 & 18.0 & 6.0 & 30.0 & 6.0 & $>48.0$ & - & - \\
\hline Cycle time (h) & \multicolumn{3}{|c|}{$\leftarrow 24.0 \rightarrow$} & \multicolumn{2}{|c|}{$\leftarrow 36.0 \rightarrow$} & & & \\
\hline $\begin{array}{l}\text { DNA Synthesis ratio* } \\
\text { (relative width) }\end{array}$ & $\begin{array}{c}1.0 \\
(0.4-1.4)\end{array}$ & & $\begin{array}{c}4.0 \\
(2.4-5.6)\end{array}$ & & $\begin{array}{c}8.4 \\
(4.6-12.4)\end{array}$ & & - & \\
\hline $\begin{array}{l}\text { c-Myc content ratio* } \\
\text { (relative width) }\end{array}$ & $\begin{array}{c}1.0 \\
(0.6-1.6)\end{array}$ & & $\begin{array}{c}2.8 \\
(2.0-3.6)\end{array}$ & & $\begin{array}{c}4.8 \\
(3.4-6.4)\end{array}$ & & - & \\
\hline \multicolumn{9}{|l|}{$\langle$ Meth-A cells $\rangle$} \\
\hline Phase Durations (h) & 4.2 & 13.0 & 8.3 & 19.4 & 14.2 & 18.8 & 29.6 & - \\
\hline Cycle time (h) & & \multicolumn{2}{|c|}{$\leftarrow 21.3 \rightarrow$} & $\leftarrow 33$ & $6 \rightarrow$ & \multicolumn{2}{|c|}{$\leftarrow 48.4 \rightarrow$} & \\
\hline $\begin{array}{l}\text { DNA Synthesis ratio* } \\
\text { (relative width) }\end{array}$ & $\begin{array}{c}1.0 \\
(0.5-1.7)\end{array}$ & & $\begin{array}{c}1.2 \\
(0.5-2.5)\end{array}$ & & $\begin{array}{c}1.8 \\
(0.8-2.9)\end{array}$ & & - & - \\
\hline $\begin{array}{l}\text { c-Myc content ratio* } \\
\text { (relative width) }\end{array}$ & $\begin{array}{c}1.0 \\
(0.6-1.4)\end{array}$ & & $\begin{array}{c}1.2 \\
(0.7-1.5)\end{array}$ & & $\begin{array}{c}1.4 \\
(0.7-2.0)\end{array}$ & & - & - \\
\hline
\end{tabular}

* values at the mid-S phase.
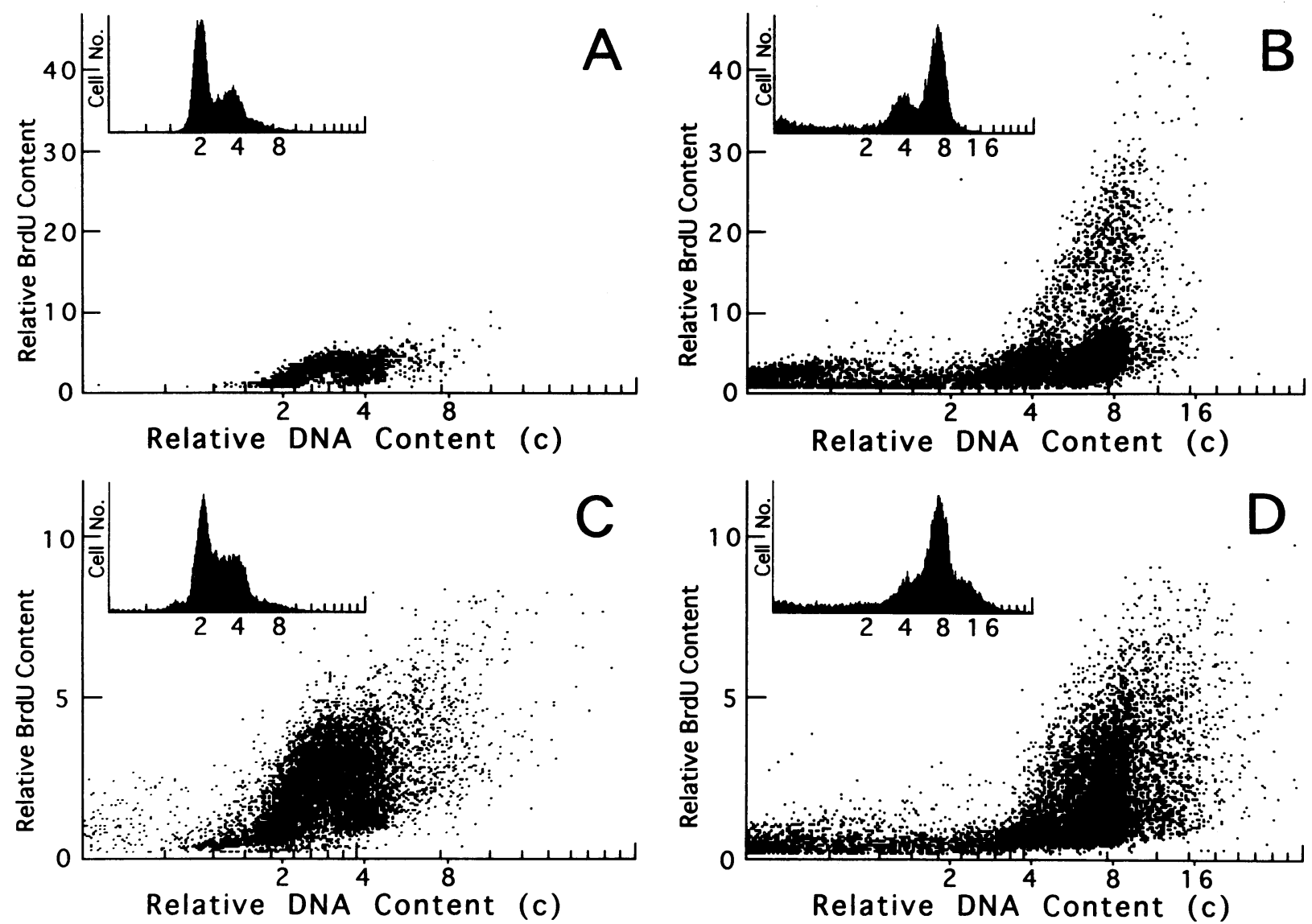

Fig. 3. Representative BrdU/DNA cytograms of B16F10 (A and B) and Meth-A (C and D) cells, and the DNA histograms (insert figures). Exponentially growing B16F10 and Meth-A cells were exposed to demecolcine of $0.1 \mu \mathrm{g} / \mathrm{ml}$. At various times, the cells were exposed to BrdU for 30 min, and stained with anti-BrdU antibody and PI. BrdU/DNA cytograms and the histograms were then obtained. In each cytogram, the ordinate and the abscissa represent the BrdU and DNA content, respectively. Note that the scale of BrdU content differs between B16F10 cells (A and B) and Meth-A cells ( $C$ and D). The insert figures represent the DNA histograms for the cytograms. Panels A and C are of the control, and panels B and $\mathrm{D}$ are the histograms 48 hours after demecolcine addition. 

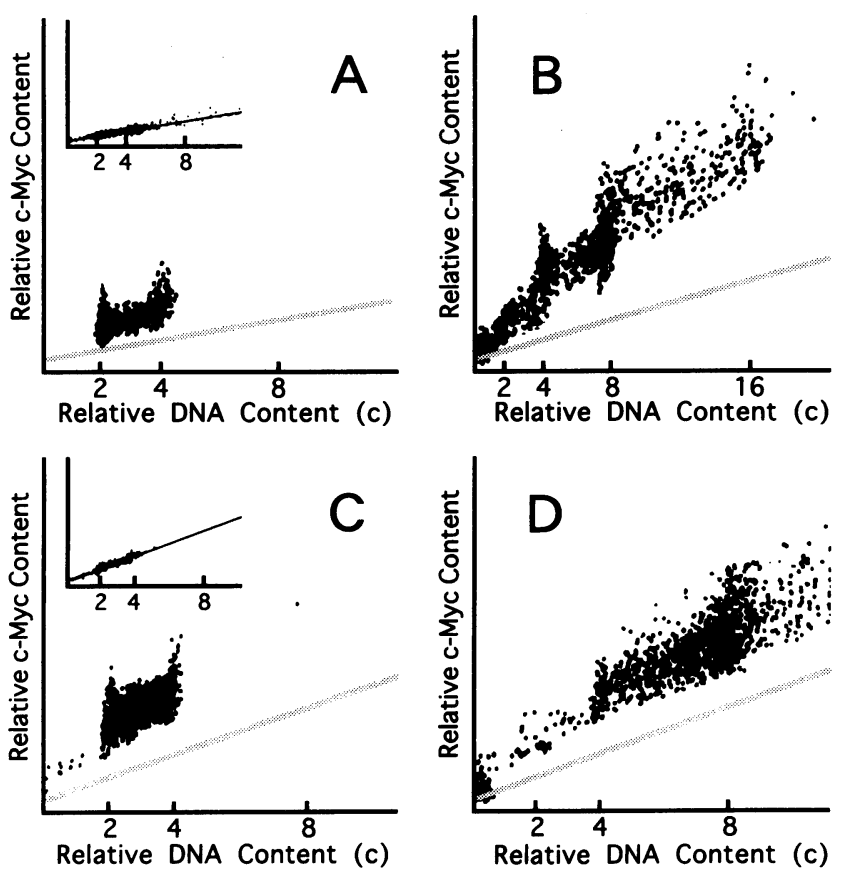

Fig. 4. Representative c-Myc/DNA cytograms of B16F10 (A and B) and Meth-A (C and D) cells. Exponentially growing B16F10 and Meth-A cells were exposed to demecolcine of $0.1 \mu \mathrm{g} / \mathrm{ml}$. At various times, the cells were stained with anti-c-Myc antibody and PI, and cMyc/DNA cytograms were obtained. In each cytogram, the ordinate and the abscissa represent the c-Myc and DNA contents, respectively. The insert figures represent the negative control in which cells were stained with $\mathrm{PBS}^{(-)}$instead of the first antibody. Dotted bands represent the base lines. Panels $\mathrm{A}$ and $\mathrm{C}$ are of the control, and panels $\mathrm{B}$ and $\mathrm{D}$ are the cytograms 40 and $30 \mathrm{~h}$ after the drug addition, respectively.

14). It has been reported that the duration of $S$ phase in mammalian cells is almost constant regardless of the ploidy (6), suggesting that certain substances, such as enzymes and DNA precursors, are responsible for the rate-limiting step of DNA synthesis increase with the DNA level. Although many studies have noted the mechanism of polyploidization of cultured cells $(1,2,7$, $15,18-21)$, increasing duration of the $S$ phase in the process of polyploidization has not been reported.

We showed an exception that the duration of S phase increased with the ploidy increase in Meth-A cells. The prolongation in $\mathrm{S}$ phase is in harmony with the results that the rate of DNA synthesis, as well as c-Myc content, was almost constant in the level of magnitude. It should be mentioned that the length of $\mathrm{G}_{2} / \mathrm{M}+$ $\mathrm{G}_{1}$ phase markedly increased with ploidy increase in B16F10 cells, but it did not increase in Meth-A cells. If the increase of $\mathrm{G}_{2} / \mathrm{M}+\mathrm{G}_{1}$ phase primarily depends on that of $G_{1}$ phase, the elongation of $G_{1}$ phase might be used to accumulate the substances for the subsequent DNA synthesis in B16F10 cells. It seems that Meth-A cells enter the polyploid $S$ phase without accumulating the substances required in DNA synthesis.

B16F10 cells responded per the hypothesis that duration of $\mathrm{S}$ phase in mammalian cells is almost constant regardless of the ploidy (6). These acceptable results with B16F10 cells may confirm the validity of our findings with Meth-A cells. Many studies have shown polyploidization of cells by drugs, such as mitotic poisons $(11,12$, 16), topoisomerase inhibitors (22) and kinase modulators (17), and different responses among cell species in the polyploidization were also noted $(12,16)$. Though we presently did not demonstrate the difference in cellular substance between Meth-A and B16F10 cells, except for cellular c-Myc content, further findings on the number of replicon, the elongation speed in DNA replication and the content of DNA polymerase may reveal the mechanism of polyploidization in Meth-A cells.

It should be emphasized that this study of the cellular response to a specific drug refers only to intracellular variations in Meth-A and B16F10 cells cultured under defined proliferating conditions.

Acknowledgments. This study was supported in part by a grant from the Project Research Fund of Kanazawa Medical University (P96-2, 1996).

\section{REFERENCES}

1. Brenneisen, P., Gogol, J., and Bayreuther, K. 1994. DNA synthesis and Fos and Jun protein expression in mitotic and postmitotic WI-38 fibroblasts in vitro. Exp. Cell Res., 211: 219230.

2. ENOCH, T. and NURSE, P. 1990. Mutation of fission yeast cell cycle control gene abolishes dependence of mitosis on DNA replication. Cell, 60: 665-673.

3. Fujikawa-Yamamoto, K., Teraoka, K., and Odashima, S. 1994. Hyperploidization of V79 cells by K-252a in comparison with demecolcine. Cell Struct. Funct., 18: 449-455.

4. Fujikawa-Yamamoto, K., Zong, Z., Teraoka, K., Yamagishi, H., and Odashima, S. 1994. Hyperploidization of Meth-A and $\mathrm{B} 16 \mathrm{~F} 10$ cells by $\mathrm{K}-252 \mathrm{a}$ and staurosporine. Cytometry Res., 4: 29-33.

5. Gong, J., Traganos, F., and Darzynkiewicz, Z. 1993. Simultaneous analysis of cell cycle kinetics at two different DNA ploidy levels based on DNA content and cyclin B measurements. Cancer Res., 53: 5096-5099.

6. Graves, J.A. and McMillan, J. 1984. Control of DNA synthesis in polyploid mammalian cells. J. Cell Physiol., 121: 409414.

7. Jordan, M.A., Wendell, K., Gardiner, S., Derry, W.B., Copp, H., and WiLSON, L. 1996. Mitotic block induced in HeLa cells by low concentrations of paclitaxel (Taxol) results in abnormal mitotic exit and apoptotic cell death. Cancer Res., 56: 816-825.

8. KRISHAN, A. 1975. Rapid flow cytofluorometric analysis of mammalian cell cycle by propidium iodide staining. J. Cell Biol., 66: 188-193.

9. Mead, J.E. and Fausto, N. 1989. Transforming growth factor alpha may be a physiological regulator of liver regeneration by means of an autocrine mechanism. Proc. Natl. Acad. Sci. 
USA, 86: $1558-1562$.

10. Pietu, G., Chany, E., Molimard, R., and Frayssinet, C. 1978. Control of cell multiplication: Preparation and immunological comparison of inhibitory factors in the homogenate and perfusate of the adult rat liver. Biomedicine, 28: 169-175.

11. Pokorny, E., Szikla, K., and Holczinger, L. 1983. The effect of N-formylleurosine on DNA synthesis of Ehrlich ascites tumor. Eur. J. Cancer Clin. Oncol., 19: 1113-1119.

12. Szaniwska, B., BJerkvig, R., Laerum, O.D., and Undheim, K. 1986. Growth arrest and polyploidization induced by methahalone microtubule inhibitors on rat glioma cells in culture. Anticancer Res., 6: 71-77.

13. Takanari, H., NaKakUki, K., and IzUTU, K. 1985. Cytogenetic demonstration of out-of phase DNA synthesis in endoreduplicated CHO cells: evidence for partial endoreduplication. Cytogenet. Cell Genet., 39: 93-98.

14. Tamura, J., Tanaka, J., Fujta, K., Yoshida, M., Kasamatsu, T., ARII, S., and Tobe, T. 1992. Effect of anticancer agents on cell cycle of regenerating hepatocytes in rat. $J$. Surg. Res., 53: 218-226.

15. Usui, T., Yoshida, M., Abe, K., Osada, M., Isono, K., and BEPPU, T. 1991. Uncoupled cell cycle without mitosis induced by a protein kinase inhibitor, K-252a. J. Cell Biol., 115: 12751282 .

16. VAN DeR Loo, B., Hong, Y., HANCOCK, V., Martin, J.F., and ERUSALIMSKY, J.D. 1993. Antimicrotubul-agents induce polyploidization of human leukaemic cell lines with megakaryocytic feature. Eur. J. Clin. Invest., 23: 621-629.
17. Vinogradov, A.E., Ezhevsky, S.A., Rosanov, J.M., KaZHDan, I.A., and ZweIBaCh, A.S. 1991. Loosing of cell cycle controls of human lymphocytes under the action of tumor promoter TPA. Cell Prolif., 24: 493-505.

18. Watters, D.J., Beamish, H.J., Marshall, K.A., Gardiner, R.A., Seymour, G.J., and Lavin, M.F. 1994. Accumulation of HL-60 leukemia cells in $\mathrm{G}_{2} / \mathrm{M}$ and inhibition of cytokinesis caused by two marine compounds, bistraten A and cycloxazoline. Cancer Chemother. Pharmacol., 33: 399-409.

19. ZhANG, Y., WANG, Z., and RAVID, K. 1996. The cell cycle in polyploid megakaryocytes is associated with reduced activity of cyclin B1-dependent cdc2 kinase. J. Biol. Chem., 271: 42664272.

20. Zong, Z., Fujikawa-Yamamoto, K., Teraoka, K., Yamagishi, H., Tanino, M., and Odashima, S. 1994. Potentiation of K252a, a protein kinase inhibitor-induced polyploidization by cAMP in cultured fibrosarcoma cell line. Biochem. Biophys. Res. Commun., 205: 746-750.

21. Zong, Z., Fujikawa-Yamamoto, K., Teraoka, K., Yamagishi, H., Tanino, M., and Odashima, S. 1995. The important role of PKC in controlling polyploidy formation in cultured fibrosarcoma cell line. Biochem. Mol. Biol. Intern., 35: 1009-1015.

22. Zucker, R.M., Adams, D.J., BaiR, K.W., and Elstein, K.H. 1991. Polyploidy induction as a consequence of topoisomerase inhibition. A flow cytometric assessment. Biochem. Pharmacol., 42: 2199-2208.

(Received for publication, April 9, 1997

and in revised form, June 23, 1997) 